https://doi.org/10.18485/bogoljub_stankovic.2018.ch11

811.161.1'373.7

\author{
ЕЛЕНА МИХАЙЛОВНА МАРКОВА* \\ Московский государственный областной университет, Москва \\ Университет Св. Кирилла и Мефодия, Трнава \\ «СУДЬБА» В РУССКОМ ЯЗЫКОВОМ СОЗНАНИИ \\ НА ИНОСЛАВЯНСКОМ ФОНЕ
}

\begin{abstract}
В статье речь идёт о смысловом объёме и средствах языковой объективации концепта cygbбa в русском языке в сопоставлении со славянскими языками (чешским, словацким, сербским, хорватским). В результате сопоставительного анализа устанавливается формально-смысловая специфика данного ментально-лингвального феномена в русской языковой картине мира.

Ключевые слова: языковая картина мира, вербализация концепта, славянские языки, русская лингвокультура
\end{abstract}

\title{
Elena Mikhailovna Markova
}

\section{?FATE? IN THE RUSSIAN LANGUAGE CONSCIOUSNESS IN COMPARISON TO THE CROSS-SLAVIC CONTEXT}

In this article we investigate the content and resources that are used for language objectivization of the concept fate in Russian in comparison to other Slavic languages (Czech, Slovak, Serbian, Croatian). As a result of the comparative analysis we establish this cognitive and linguistic phenomenon based on the form and meaning in the Russian language conceptualization of the world.

Key words: language picture of the world, verbalization of the concept, Slavic languages, Russian linguoculture

В число концептов большинство лингвистов включают лексемы, значения которых составляют содержание национального языкового сознания и формируют «наивную картину мира» носителей языка, образуя концептосферу данного языка. В более узком понимании к числу концептов относят семантические образования, отмеченные лингвокультурной

\footnotetext{
*elena-m-m@mail.ru
} 
спецификой и тем или иным образом характеризующие носителей определённой этнокультуры. Наличие у слова национально-культурной специфики признается фактором, придающим ему статус концепта (Нерознак 1998: 85). В качестве этноспецифического может выступать и признак, положенный в основу номинации - внутренняя форма слова. На наш взгляд, совокупность признаковых основ лексем, объективирующих какой-либо концепт, и составляет его ядро. С целью выявления релевантных, ядерных признаков концепта $c y g b \delta a$ в русском языковом сознании и соотнесении их со смысловым объёмом в других славянских языках (чешском, словаком, сербском, хорватском) мы обратились к анализу внутренней формы вербализующих его лексем.

В русском языке понятие «судьба» транслируется многочисленным рядом лексем: суgьба, суgьбина, gоля, уgел, юооль, участь, иасть, крест, Голгофа, планияа, рок, фатум, преgначертание, преgназначение, провияение, промысел, фортуна, жребий (РСС), gорога, путь, росстань. Хотя в смысловом отношении перечисленные лексемы очень близки, их нельзя назвать синонимами, т. к. каждая из них характеризует анализируемый концепт со своей стороны, объективируя собой не только первоначальное представление, но и коннотацию - положительную или отрицательную.

Суgьба определяется толковыми словарями как 'то, что суждено, предначертано свыше, ход жизни, не зависящий от воли человека' (РСС), 'стечение обстоятельств', 'участь, доля, жизненный путь', но первоначальное значение - 'воля божества, предопределяющая все, что происходит в жизни' (ТСРЯ). Недаром синонимами этого слова в русском языке являются лексемы преgопреgеление, преgназначение, преgначертание, провияение (часто в сочетании воля провияения), промысел (в сочетании промысел Божиц̆), определяющие судьбу как нечто заранее написанное, начертанное, назначенное, увиденное, мысленное кем-то сверху. В чешском и словацком языках им соответствуют лексемы předurčení 'предопределение', řizení boží 'Божий промысел', boží vi̊le 'воля Божья', boží prozřetelnost 'Божье провидение', predestinace 'предопределение', predeterminace 'предзнаменование', providence 'провидение', в сербоком и хорватском - predodređenost 'предопределение', predestinacija 'предопределение'.

Ядерная лексема суgьба имеет общеславянский характер и является производным от *sodz 'суд', бытуя в болгарском, сербском, хорватском, словацком языках. В чешском в этом значении используется однокоренное osud 'судьба', в сербском и хорватском известно и ныне устаревшее sudbina 'судьба' (скорее всего, из рус. суgьбина, но с амбивалентной семантикой в отличие от русского коррелята). В древнерусском языке известно с XI в. в значениях 'суд', 'судилище', 'правосудие', 
'приговор'. Однако уже И. И. Срезневский отмечал семему 'предопределение'. Предположительное развитие значений: 'божий суд' ('приговор небесных сил') $\rightarrow$ 'предопределение', 'рок' (ИЭСРЯ). Поэтому изначальное понимание судьбы - 'то, что предписано, предопределено Богом', т. е. происходит вне воли человека, о чём свидетельствует и устойчивая синтагматика этой лексемы: превратности суgьбы 'резкие и неожиданные повороты в жизни', ирония суgьбы 'странная случайность', (книжн.) nерст cygbбы 'о том, что явилось определяющим событием в чьей-л. жизни', поgарок суgьбы 'о большой и неожиданной удаче, радости', (книжн.) волею суgеб 'случайно', избранник суgьбы 'счастливец', бросить кого-л. на произвол суgьбы 'не заботясь о положении кого-л., оставить в беспомощном состоянии', суgьба улььбнулась 'повезло', (разг., шутл.) суgьба-инgейка 'о незадачливой, трудной судьбе', испьтьвать, искушать суgьбу 'делать что-л. сопряжённое с излишним риском'.

Слово рок, производное от ректи 'говорить', вначале значило 'предсказанное', откуда в дальнейшем развилось значение 'судьба' (аналогичное семантическое развитие свойственно и его синониму фатум из лат. fatum 'судьба' от лат. fari 'говорить'). Затем лексема рок стала использоваться для обозначения времени, срока. Семантическая структура её в древнерусском языке включала в себя значения: 'срок', 'год', 'возраст', 'судьба'. Несмотря на то что сема 'судьба' у лексемы рок в словаре древнерусского языка И. И. Срезневского представлена последней, это не отражает путь смыслового развития слова. Этимологически значение данного слова восходит к тому, что преgречено, преgсказано, то есть к значению современного русского рок. Впоследствии только в русском языке оно вышло из активного употребления в своих «временных», более поздних, значениях, сохранившись для обозначения судьбы (обычно несчастливой). «Отрицательная» коннотация этого слова связана с тем, что предсказания чаще всего касались несчастий, смерти, поэтому их боялись. При этом оно имеет стилистическую окраску возвышенности, приподнятости и встречается в устойчивых выражениях: злой рок, рок преслеgyem, а также в составе прилагательного роковой (т. е. трагический, зловещий). Вместе с тем в других славянских языках (напр., чешском, словацком) rok обозначает 'год', таким образом, в этих языках сохранилось более позднее, темпоральное, значение. В чешском, словацком, сербском, хорватском в этом значении используется заимствованное fatum, однако в хорватском известно и слово с аналогичной мотивемой sreća (букв. 'изречённое'). В сербскк-хорватском языковом ареале бытует и слово kob в значении 'судьба, рок, фатум' (по мнению этимологов, пришедшее из средневековой латыни и известное в древности и в других славянских языках), образованное от ст.-нем. kobbe 'ворон' (ESJČM). Это метонимическое значение связано с тем, что крик ворона считался 
плохой приметой, имел плохое предзнаменование, предвещал, гибель (вороны, как известно, слетаются на мёртвые тела). В русском языке известен когнитивно близкий глагол каркать (первоначально о звуках, издаваемых вороном, а затем в переносном значении: 'предрекать, высказывать предположения о чём-то плохом').

Рус. жребий в современном русском языке также обозначает судьбу и имеет, как и лексема рок, в словарях маркировку 'высокое, книжное' (в то время как его этимологический коррелят чеш. hřebík (ст.-чеш. hřebí) относится к артефактной лексике и обозначает 'гвоздь'). Оба рефлекса восходят к деривату от праславянского *žerb (*greb) 'вырывать, вытягивать', первоначально обозначавшему 'колышек, при помощи которого вытягивались номера, знаки при жеребьёвке или предсказании' (SČS). Так семантика этимона, включающая в себя несколько признаков, послужила основанием для развития отдельных его признаков в разных славянских языках. В чешском языке семантическая эволюция лексемы была следующая: 'деревянный колышек' $\rightarrow$ 'гвоздь' (который вначале был деревянным). Другое направление семантического развития, представленное в русском языке, основано на метонимическом переносе и связано с тем, что деревянный колышек указывал на выпавший жребий, судьбу: 'колышек, указывающий на выпавший жребий' $\rightarrow$ 'жребий как выпавший номер' $\rightarrow$ 'жребий, судьба, рок'. Отсюда наличие энантиосемичных векторов в семантике и соответствующего лексического окружения: жалкий жребий, выпал труяный жребий и сиастливый жребий. Свидетельством совмещённости первичных значений является семантика ст.-чеш. hřebí, объединявшая семемы 'жребий, рок, судьба' и 'гвоздь' (SČS). Первая из них впоследствии была утрачена чешской лексемой, но стала основной для ст.-слав. жребиц̆, откуда это слово было заимствовано в русский язык (исконно русский вариант этого корня - жереб-, ср. жеребъёвка). Известно в виде žreb и в словацком языке, который в лексическом плане ближе к русскому, чем чешский. В чешском же в этом значении в силу исторических причин (длительного господства немецкого языка как государственного) закрепилось заимствованное из немецкого los, которое бытует во многих выражениях, напр.: volit losem 'выбирать по жребию', padl na něho los 'на него пал жребий', metat los 'бросать жребий', zlý los 'злой рок', а также в качестве корня в словах losovat 'метать жребий, проводить жеребьёвку', losování 'жеребьёвка', откуда и слово loterie - рус. лотерея. Таким образом, идея случайного выбора, случайности в судьбе присутствует во всех языках.

В рассматриваемом синонимическом ряду в русском языке лишь слово фортуна имеет положительную коннотацию, манифестируя собой счастливый случай, удачу, которые могут изменить трагический ход событий. Слово было заимствовано в Петровскую эпоху из латинского 
языка, где оно было образовано от fors 'случай, неожиданность' (откуда форс-мажорные обстоятельства), затем 'удача' от глагола ferre 'носить' $\rightarrow$ 'преподносить, ниспосылать', т. е. буквально фортуна - 'ниспосланное (Богом)' (КЭСРЯ). Этим именем была названа римская богиня счастья, удачи и случая, изображающаяся с рогом изобилия, иногда на колесе или с символической повязкой на глазах, с чем связаны выражения: $\delta a-$ ловень фортуны 'счастливчик', фортуна слепа, превратности фортуны, колесо фортуны 'изменчивое, непостоянное счастье', в которых положительная судьба предстаёт непостоянной, случайной, временной. На мелиоративную семантику данной лексемы указывают и родственные просторечные дериваты из воровского жаргона поgфартило - 'повезло' от фартить 'везти', 'удаваться', фартовый 'удачливый' (ТСРЯ).

В дальнейшем лексема $c y g ь \delta a$ развила конверсивную семантику 'то, что происходит с кем-л., события жизни; история существования кого-чего-л.' на основе метонимического переноса: 'высшие силы, определяющие что-то' $\rightarrow$ 'то, что определяется высшими силами'. При этом потенциально в семантике лексемы заложена возможность амбивалентного развития, ведь судьба в этом смысле может быть как хорошей, удачной, так и плохой, тяжёлой, наполненной страданиями и трудностями, поэтому все лексемы, связанные с выражением этой семантики, коннотативно окрашены, чаще всего имеют пейоративную коннотацию.

Мотивационно, когнитивно и коннотативно близкими являются русские лексемы gоля, уgел, преgел и уиасть. Доля относится к исконно русским суффиксальным образованиям от gелить (т. е. буквально 'то, что отделено', 'часть'), так же как и уgел. Уиасть также является собственно русским дериватом от иасть (КЭСРЯ). Таким образом, все три лексемы: gоля, уgел и уиасть - обозначая первоначально нечто отделённое, часть, затем развили в русском языке на основании метафорического переноса абстрактное значение 'судьба' в смысле 'часть, выделенная Всевышним'. Две из них: gоля и участь - устойчиво используются с негативной коннотацией, что выражается в их частотных синтагматических связях, ср.: женская gоля, бабья gоля, сиротская gоля, выпасть на чью-л. долю, тянёлая участь, горькая участь, участь быть убитым, разделить иью-л. печальную участь и т. п., хотя возможны и антонимичные сочетания: сиастливая gоля, сиастливая уиасть. Слово удел, став устаревшим, закрепилось в книжной речи чаще всего в мелиоративном значении в выражениях: сиастливый уgел, gостаться в удел кому-н., хотя его просторечный вариант преgел обозначает тяжёлую, трудную судьбу, что представлено, например, в следующем контексте: Такой уж, вияно, ему предел был на чужбине умереть. Ещё более высоким является старославянский вариант лексемы уgел - юgоль, которое можно встретить, например, в сочетании земная юgоль, т. е. 'жизнь с её печалями и забо- 
тами', в котором также чувствуется тяготение к отрицательной эмоциональности. В чешском и словацком языках из слов с данной внутренней формой используется údél, в серббском и хорватском udes, udio.

Отрицательную коннотацию, связанную с представлениями о несчастливой судьбе, тяжёлой участи, имеют и синонимичные лексемы суgьбина (обычно горькая суgьбина), (прост.) планияа (ср. типичный контекст: выпала злая планияа). Во многом это обусловлено религиозными причинами: связано с трагической судьбой Иисуса Христа, с его страданиями за человечество, что обусловило изменение семантики лексем крест и Голгофа, которые стали метонимически употребляться как синонимы несчастной, страдальческой, тяжкой судьбы, что вербализуют фраземы: нести свой крест, ияти на Голгофу.

Ещё одним ярким примером концептуального развития является эволюция значения слова gорога в русском языковом сознании. Лексема является суффиксальным образованием от gьрати 'драть, чистить' и означала буквально 'расчищенное (для прохода) место' (КЭСРЯ). Тот же признак положен и в основу чеш. cesta 'дорога', деривата от общеславянского иистить (ČES), в отличие от русского коррелята, не получившего семантического развития, связанного с концептом «судьба». О концептуальном, символическом развитии семантики этого слова в русском языке свидетельствуют такие сочетания, как жизненная gорога, жизненный путь, gорога жизни, gорога смерти, а также сигнификативно связанного с ним понятия перекрещивающихся дорог, обозначаемых лексемами перекрёсток, перепутье, распутье, росстань. В других славянских языках есть денотативно эквивалентные лексемы чеш. rozcestí 'распутье', křižovatka 'перекрёсток', хорв. raskršće, raskrsnica 'распутье', križanje 'перекрёсток', raskrižje (putova) 'перепутье дорог', но в значении рус. стоять на pacnутье используются чеш. být na rozpacích, слвц. byt $v$ rozpakoch 'быть в смущении, замешательстве', хорв. biti u nedoumici, $u$ dilemi 'быть в недоумении, решать дилемму'. Таким образом, слово gорога и его синонимы распутье, перепутье, перекрёсток, росстань получили дальнейшее смысловое распространение, связанное с концептом суgьба, только в русском языке.

Слово росстань приобрело особенно важный смысл для русского языкового сознания, обросло многочисленными смысловыми наращениями, уходящими корнями в древнюю мифологию и отражающими представления и мировосприятие русского человека, поэтому мы решили остановиться на нем подробнее. Оно принадлежит к единицам национального русского языка, находящимся на языковой периферии и малознакомым или вообще неизвестным обычному носителю русского языка, вместе с тем широко распространённым в диалектах, в особен- 
ности севернорусских, в говорах Урала и Сибири, примыкающих к ним, а также в художественной речи. Лексема росстань известна еще с древнерусского периода, чему существует документальное подтверждение: оно зафиксировано в Словаре русского языка XI-XVII вв.: 'Росстани (Ростани), мн. Разветвление дорог или перекресток' (СРЯ XI-XVII). В современном русском языке денотативное значение лексемы росстань не изменилось (ТСРЯ).

Лексема имеет «прозрачную» внутреннюю форму, прямо указывающую на этимологию, что способствовало её закреплению и распространению не только в диалектной речи, но и в литературе. Её мотивом послужил глагол расставаться / расстаться, - 'место, где расстаются'. Во внутренней форме лексемы росстань заложены большие семантико-коннотативные потенции, что является важным фактором его дальнейшего концептуального развития. В отличие от его синонимов перекрёсток, pазgорожье, перепутье, распутье, развилка, мотивационно связанных с понятиями 'перекрещиваться, пересекаться', 'дорога', 'путь', 'вилять, поворачивать', слово росстань эксплицирует собой признак 'расставание', что рождает целый шлейф дополнительных смыслов.

Словарь русских народных говоров зафиксировал следующие варианты употребления слова росстань в севернорусских диалектах: 'перекрёсток или разветвление дорог, развилка'; 'дорожка, отходящая от большой дороги'; 'место слияния двух ручейков'; 'расставание, прощание на перекрёстке дорог, разлука' (СРНГ). В сознании русского народа росстань обладает мифологическим смыслом, с ней были связаны обряды, общение с «нечистой силой», гадания. Считалось, что на росстани можно получить предсказание. Толковалось гадание по характеру звуков, которые были слышны на месте гадания, от чего пошло выражение слушать на росстани. Росстань как «предсказатель» фигурирует и в русских былинах и русских сказках. Непременным сюжетным элементом их является выезд богатыря или сказочного героя на росстань, развилку. Обычно герой обнаруживает там камень или столб с надписью, указывающей варианты предстоящей ему судьбы: быть 'убиту', 'женату', 'богаmy'. Таким образом, в русском фольклоре слово росстань приобретает ярко выраженную мифолого-поэтическую символику, становясь мифологемой, связанной с понятиями «прощание», «предсказание», «судьба», «выбор», «гибель», «встреча».

Л. Н. Толстой, М.М. Пришвин в своих произведениях возводят слово росстань в ранг философской категории, метафорически придавая ему значение выбора жизненного пути. От того, какую росстань выберет человек, зависит вся его судьба. В дальнейшей семантической эволюции росстань вербализует собой не только выбор отдельным человеком своего личного духовного пути, но символически обозначает 
глобальный выбор целого народа. Росстань - это и символ глубокого размышления над судьбой отдельного человека и судьбой всей страны не только в исторический момент смены власти, но и в наше время. Сейчас это слово возникает в контексте размышления над тем, покидать ли деревню, уезжать ли в город, навсегда распрощавшись с сельской жизнью, и к чему это приведет, что станет с Россией. Таким образом, слово росстань концептуально соприкасается с раздумьями о судьбе России, что делает соотносимым его не только с концептом $c y g b \delta a$, но и с концептом poguнa. В произведениях русских писателей слово росстань наделяется глубоким философским смыслом, становясь и символом ониgания, и местом судьбоносной встречи, предначертанной суgьбой. Оно символически стало обозначением места разяумий, где человек останавливается и задумывается над тем, куда направить путь, какой выбор сделать. Можно представить вектор семантического развития лексемы в виде следующих семантических переходов: 'расставаться' $\rightarrow$ 'место, где расстаются' $\rightarrow$ 'выбор дороги' $\rightarrow$ 'путь' $\rightarrow$ 'судьба'.

Признаки, положенные в основу номинации, эксплицируют наивные представления народа о том или ином явлении, объекте действительности. В соответствии с этими представлениями $c y g ь \delta a$ в русском мировосприятии это не только то, что 'предсказано', 'предначертано', 'часть, выделенная Богом', 'то, на что осуждён человек Всевышним', как в других славянских языках. В этом понятии философски сталкиваются случай, удача (фортуна, сиастливый жребий) и закономерность как

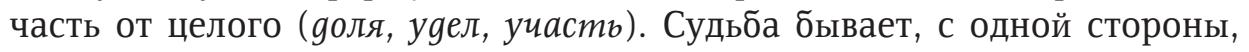
хорошая, счастливая (что выражают, в основном лексемы суgbбa (с амбивалентной семантикой), фортуна (с положительной оценочностью, ср. фортуна ульбнулась), что для русского сознания нетипично, редко, преходяще, с другой - плохая, несчастная (что бывает чаще, в представлении русских, поэтому и лексем с пейоративной коннотацией, вербализующих этот концепт в русском языке, больше: gоля, уgел, уиасть, рок, жребий, чаще всего в сочетаниях тяжелая gоля, труяная участь, злой рок, тяжкий жребий). Но, с точки зрения русского мировидения, это не снимает и с самого человека ответственности за его судьбу, его жизненный удел, т. к. cygbбa - это и выбор gороги, по которой идти в жизни, который связан с 'перепутьем, перекрёстком дорог, это и сама gорога, жизненный путь. 


\section{Использованная литература}

Нерознак, В. П. „От концепта к слову: к проблеме филологического концептуализма". Вопросы филологии и методики преподавания иностранныХ языков. Омск, 1998: 80-85.

\section{Словари и их сокращения}

Даль - Даль, В. И. Толковый словарь живого великорусского языка. В 4-х т. М., $1978-1980$.

ИЭСРЯ - Черных П. Я. Историко-этимологический словарь современного русского языка. В 2-х т. М., 1993.

КЭСРЯ - Шанский, Н. М., Боброва Т. А. Этимологический словарь русского языка. М., 1995.

РСС - Русский семантический словарь / Под общей ред. Н. Ю. Шведовой. В 3-х т. M., 2003.

СРНГ - Словарь русских народных говоров (Под ред. Ф. П. Филина). Л. - Спб., вых. с 1965.

Срезн. - Материалы для словаря древнерусского языка. в 3-х тт. М., 2003.

СС - Старославянский словарь (по рукописям Х-ХІ вв.), 2-е изд. М., 1999.

ТСРЯ - Толковый словарь русского языка в 4-х т. Под ред. Д. Н. Ушакова. М., 2007.

ЭСРЯ - Фасмер, М. Этимологический словарь русского языка. В 4-х т., 2-е изд. M., 1986.

ЭССЯ - Этимологический словарь славянских языков. Праславянский лексический фонд (Под ред. О. Н. Трубачева). М., вых. с 1974.

ESJČM - Machek, V. Etymologický slovník jazyka českého, 3-é vyd. Praha: Lidové noviny, 2010.

RHS - Rusko-hrvatski rjećnik. Zagreb: Školska knjiga. 2002.

SČS - Gebauer, J. Staročeský slovník. T. 1-2. Praha, 1903-1916.

SSČ - Slovník spisovné češtiny pro školu a veřejnost. Praha, 2003.

TJČ - Klegr, A. Tezaurus jazyka českého. Slovník českých slov a frází souznačných, blízkých a príbuzných. Praha, 2007. 
Јелена Михајловна Маркова

\section{„СУДБИНА” У РУСКОЈ ЈЕЗИЧКОЈ СВЕСТИ ИЗ ПЕРСПЕКТИВЕ ДРУГОГ СЛОВЕНСКОГ ЈЕЗИКА}

\section{Резиме}

У раду се говори о смисаоном обиму и средствима језичке објективиза-

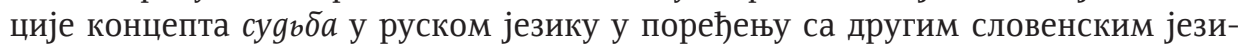
цима (чешким, словачким, српским, хрватским). На основу конфронтационе анализе установљује се формално-смисаона специфичност овог ментално-лингвалног феномена у руској језичкој слици света.

Кљуине речи: језичка слика света, вербализација концепта, словенски језици, руска лингвокултура 